\title{
Studies on 4-Hydroxyaminoquinoline 1-0xide and Its Related Compounds. Synthesis of 3-Chloro- and 3-Bromo-4-aminoquinoline 1-0xide and Presentation of Chemical Evidence for a New Type of Aromatic Rearrangement of N,0-Diaryl- hydroxylamines*
}

\author{
Hiroyuki Sawanishi ${ }^{1 a)}$ and Yo Kamiya ${ }^{1)}$ \\ Shizuoka College of Pharmacy 1 )
}

(Received April 30, 1975)

\begin{abstract}
The present paper deals with thermolyses of 4-hydroxyaminoquinoline 1-oxide (4HAQO) in acidic media and a new type of rearrangement of $\mathrm{N}, \mathrm{O}$-diarylhydroxylamine derived from $4 \mathrm{HAQO}$ and 4 -hydroxyaminoquinoline. Thermolyses of 4 -hydroxyaminoquinoline or -pyridine derivatives in hydrochloric or hydrobromic acid gave corresponding 3-halo-4-amino derivatives in relatively high yield. It was also found that $\mathrm{N}, \mathrm{O}$-di(4quinolyl)hydroxylamine and $\mathrm{N}$-(4-quinolyl)-O-(2,4-dinitrophenyl)hydroxylamine were rearranged to a corresponding diaryl derivative, $3,3^{\prime}-\left(4\right.$-amino- $4^{\prime}$-hydroxy $)$ biquinoline and 3 -(2'-hydroxy-3',5'-dinitrophenyl $)-4$-aminoquinoline, respectively. Those facts presented the first chemical evidences for an aromatic rearrangement of $\mathrm{N}, \mathrm{O}$-diarylhydroxylamine which had already been predicted by Dewar.
\end{abstract}

After the discovery of carcinogenic activity of 4-nitroquinoline 1-oxide ${ }^{2)}$ and 4-hydroxyaminoquinoline 1-oxide ${ }^{3)}(4 \mathrm{HAQO})$, many efforts have been made to elucidate the relationship between their chemical reactivity and carcinogenicity. ${ }^{4)}$ In our previous papers, ${ }^{5)}$ it has been reported that free radicals were found as intermediates in air oxidation or pyrolysis of $4 \mathrm{HAQO}$ to give diquinoline derivatives. The present paper deals with thermolyses of $4 \mathrm{HAQO}$ in acidic media and a new type of rearrangement of $\mathrm{N}, \mathrm{O}$-diarylhydroxylamine derived from $4 \mathrm{HAQO}$ and 4-hydroxyaminoquinoline (4HAQ).

1) Thermolyses of $4 \mathrm{HAQO}$ and related compounds in acidic media.

Thermolyses of 4-hydroxyamino-quinoline or -pyridine derivatives in hydrochloric or hydrobromic acid gave corresponding 3-halo-4-amino derivatives in relatively high yield.

A solution of $4 \mathrm{HAQO}$.hydrochloride in $1 \mathrm{~N} \mathrm{HCl}$ was heated at $200^{\circ}$ for 3 hours in a sealed tube. Purification with chromatography on silica gel afforded chloro-compound (1), $\mathrm{mp} 220^{\circ}$ (decomp.), $\mathrm{C}_{9} \mathrm{H}_{7} \mathrm{ON}_{2} \mathrm{Cl}, \mathrm{UV} \lambda_{\max }^{\mathrm{MeOH}} \mathrm{m} \mu(\varepsilon): 223$ (27600), 260 (12300), 372 (8750), in 79\% yield. Treatment of 1 with $n$-butylnitrite in a mixture of acetic acid and conc. $\mathrm{H}_{2} \mathrm{SO}_{4}$, followed by refluxing in $\mathrm{C}_{2} \mathrm{H}_{5} \mathrm{OH}$ to give (2), $\left.{ }^{6}\right) \mathrm{mp} 100-101^{\circ}$, Mass Spectrum m/e: $179\left(\mathrm{M}^{+}\right)$. Catalytic

* Dedicated to the memory of Prof. Eiji Ochiai.

1) Location: 2-2-1, Oshika, Shizuoka; a) Present address: School of Pharmacy, Hokuriku University, 3Ho, Kanagawa-Machi, Kanazawa.

2) W. Nakahara, F. Fukuoka, and T. Sugimura, Gann, 48, 129 (1957).

3) H. Endo and F. Kume, Naturwissenshaften, 50, 525 (1963); idem, Gann, 54, 443 (1963).

4) Y. Kawazoe, M. Tachibana, K. Aoki, and W. Nakahara, Biochem. Pharmacol., 16, 631 (1967); T. Okamoto and M. Mochizuki, Chem. Pharm. Bull. (Tokyo), 17, 987 (1969); M. Tachibana, S. Sawaki, and Y. Kawazoe, ibid., 15, 1112 (1967); Y. Kawazoe and M. Araki, ibid., 16, 839 (1968); M. Araki, Y. Kawazoe, and C. Nagata, ibid., 17, 1344 (1968); Y. Kawazoe and M. Araki, "Chemical Tumor Problems," ed. by W. Nakahara, pp. 43-104; C. Nagata, N. Kataoka, A. Imamura, Y. Kawazoe, and G. Chihara, Gann, $57,323(1966)$.

5) T. Kosuge, H. Zenda, and H. Sawanishi, Chem. Pharm. Bull. (Tokyo), 17, 2389 (1969); idem, ibid., 19, 1291 (1971).

6) T. Kauffman and J. Schulz, Chem. Ber., 99, 1837 (1966). 
hydrogenation of 2 over Raney nickel afforded a liquid (3), mp 185-186 (picrate), Mass Spectrum m/e: $163\left(\mathrm{M}^{+}\right)$. 3 was found to be identical with authentic sample ${ }^{7}$ of 3 -chloroquinoline in comparison with their spectral data and mixed melting point of their picrates. Thus, the structure of 1 was confirmed to be 3-chloro-4-aminoquinoline 1-oxide, as shown in Chart 1.

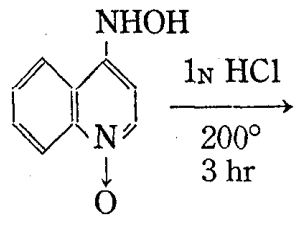<smiles>Nc1c(Cl)c[n+]([O-])c2ccccc12</smiles>

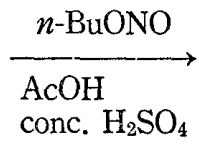<smiles>[NH3+]c1c(Cl)c[n+]([O-])c2ccccc12</smiles><smiles>Nc1cnc2ccccc2c1</smiles>
1) $n$ - BuONO AcOH
conc. $\mathrm{H}_{2} \mathrm{SO}_{4}$

2) $\mathrm{HCl} \mathrm{CuCl}_{2}-\mathrm{Cu}$<smiles>Clc1cnc2ccccc2c1</smiles><smiles>[R20]CC1CC1</smiles><smiles></smiles>

Chart 1

TABLE I. Termolysis of $4 \mathrm{HAQO}$ in $1 \mathrm{~N} \mathrm{HCl}$ at Various Temperature

\begin{tabular}{ccc}
\hline Temp. $\left({ }^{\circ} \mathrm{C}\right)$ & hr & Yield of $1(\%)$ \\
\hline 200 & 3 & 79 \\
150 & 3 & 88 \\
125 & 3 & 83 \\
100 & 18 & 64 \\
60 & 18 & trace \\
\hline
\end{tabular}

Furthermore, the thermolyses of $4 \mathrm{HAQO}$ in $1 \mathrm{~N} \mathrm{HCl}$ at lower temperature were investigated and the results were shown in Table I. It was noteworth that 1 was obtained in $64 \%$ yield even at $100^{\circ}$. This finding to give 3 -chloro derivatives in high yield on thermolyses of $4 \mathrm{HAQO}$ in hydrochloric acid prompted us to proceed the same reaction in the other 4-hydroxyaminoquinoline and -pyridine derivatives. It would be expected to be better method for the direct introduction of chlorine at 3 -position in quinolines than method of chlorination with $\mathrm{S}_{2} \mathrm{Cl}_{2}{ }^{8}{ }^{8}$ The results of the thermolyses of 4-hydroxyamino-quinoline and -pyridine derivatives in various concentration of hydrochloric acid were summarized in Table II. The structures of products were confirmed by comparison with authentic sample or analyses of their spectral data, the details of reactions will be described in experimental part.

In all compounds which were examined in this paper, reactions occurred in ortho position of hydroxylamine, namely in $\beta$-substitution of quinolines or pyridines. The reactions of $4 \mathrm{HAQ}$ and 9 were accompanied by hydrolyses of amine to afford 4-hydroxy derivatives.

Thermolyses of $4 \mathrm{HAQO}, 4$ and $4 \mathrm{HAQ}$ in $2 \mathrm{~N} \mathrm{HBr}$ were examined, and did not give any bromo compounds, but reduction of hydroxyamino to amino was observed as shown in Table III. But in conc. $\mathrm{HBr}$, the thermolysis of $4 \mathrm{HAQO}$ was performed to give 3-bromo-4-aminoquinoline 1-oxide (19) in $71 \%$ yield, as such as chlorination. The structure of the bromo

7) J.C. Cochran and W.F. Little, J. Org. Chem., 26, 808 (1961).

8) Edinger and Lubberger, J. Prakt. Chem., 54, 348; Edinger, Chem. Ber., 29, 2456 (1896) [Beilstein, 20, 359]; R.H. Baker, C.J. Albisetti, Jr., R.H. Dodson, G.R. Lappin, and B. Riegel, J. Am. Chem. Soc., 68, 1532 (1946); F.H. Case, S. Catino, and F. Scholnick, J. Org. Chem., 19, 31 (1954); W.O. Sykes, J. Chem. Soc., 1958,$825 ;$ etc. 
compound (19) was confirmed by comparison with the authentic sample.9) It was well known as Bamberger reaction ${ }^{10}$ that arylhydroxylamine is easily rearranged to $o$ - or $p$-hydroxyaniline derivative in acidic medium, however in a field of $\mathrm{N}$-heteroaromatic compound this kind of reaction has not been reported before our finding in this paper. Recent reports ${ }^{11,12 a)}$ studied

TABLE II. Thermolyses of Hydroxylamine Derivatives in Various Concentration of Hydrogen Chloride

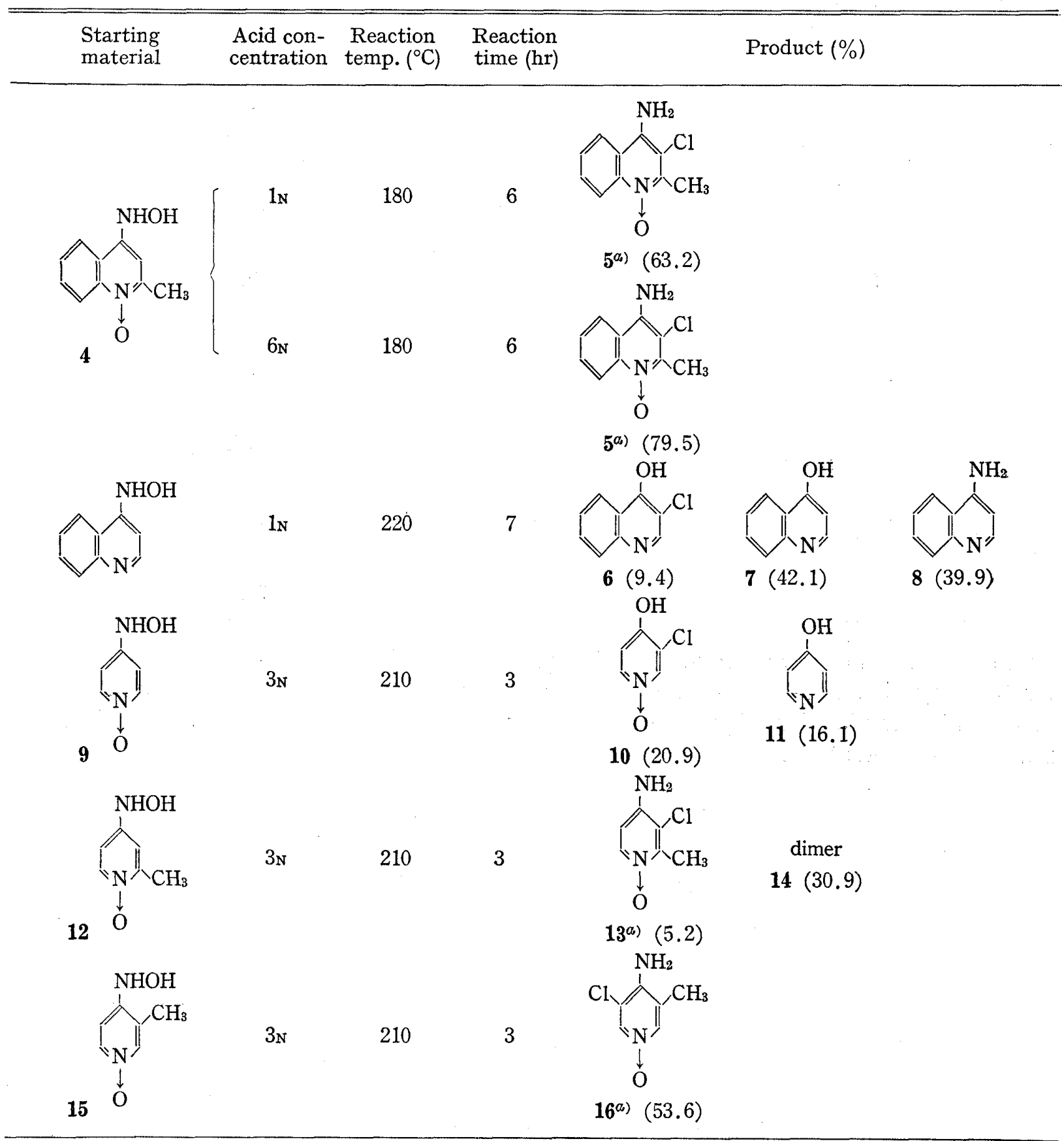

a) The structure was confirmed by spectral data listed in experimental part.

9) T. Naito, Yakugaku Zasshi, 67, 246 (1964).

10) E. Bamberger, Chem. Ber., 27, 1347 (1894); idem, Ann., 424, 233 (1921).

11) H.E. Heller, E.D. Hughes, and C.K. Ingold, Nature, 168, 909 (1951); Y. Yukawa, Nippon Kagaku Zasshi, 71, 603 (1950); K. Shudo, Yuki Gosei Kagaku Kyokai Shi, 31, 395 (1973).

12) a) M.J.S. Dewar, "Molecular Rearrangement," Vol. I ed. by P. De Mayo, Interscience, New York and. London, 1963, p. 308; b) Idem, ibid., p. 344. 
TABLE III. Thermolyses of Hydroxylamine Derivatives in $2 \mathrm{~N}$ and conc. Hydrogen Bromide

Acid con-
centration $\begin{gathered}\text { Reaction } \\ \text { temp. }\left({ }^{\circ} \mathrm{C}\right)\end{gathered} \begin{gathered}\text { Reaction } \\ \text { time }(\mathrm{hr})\end{gathered}$ Product (\%)

on the mechanism for Bamberger reaction prompted us to propose a plausible mechanism for the formation of 3-halo-4-amino compounds, namely these reactions were considered to proceed via nitrenium ion (20) resulted from heterolytic fission of $\mathrm{N}-\mathrm{O}$ bond, as shown in Chart 2 in the case of $4 \mathrm{HAQO}$.

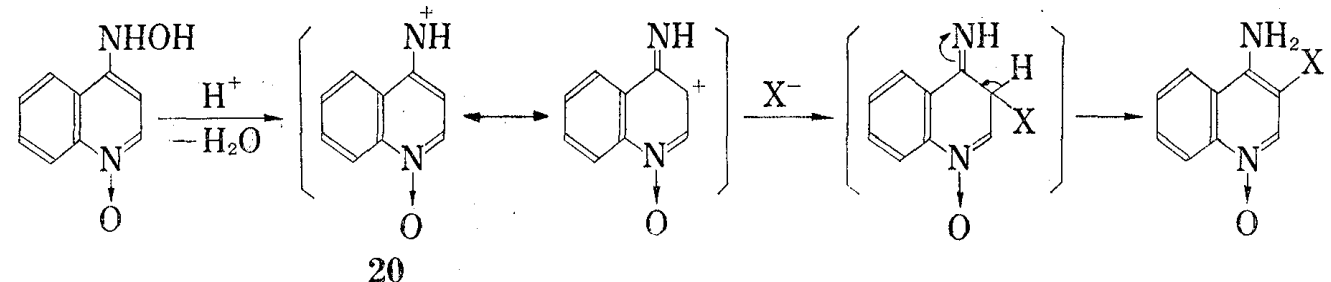

Chart 2

Further investigation of this series and more precise study on the mechanism are in progress.

2) Presentation of chemical evidences for a new aromatic rearrangement of $\mathrm{N}, \mathrm{O}$-diarylhydroxylamines.

As further study on the heterolytic N-O bond fission, it was found that N,O-diquinolylhydroxylamine was easily rearranged to biquinoline derivatives. This section in the paper deals with the new type of reaction in $4 \mathrm{HAQ}$.

A mixture of 4-chloroquinoline (21) and hydroxylamine in $\mathrm{CH}_{3} \mathrm{OH}$ was heated under refluxing for 5.5 hours to give (22), $\mathrm{mp}>300^{\circ}(\mathrm{HCl}$ salt $), \mathrm{C}_{18} \mathrm{H}_{13} \mathrm{ON}_{3} \cdot 3 \mathrm{HCl} \cdot \mathrm{H}_{2} \mathrm{O}$, Mass Spectrum $m / e: 287\left(\mathrm{M}^{+}\right)$, and (23), mp $168^{\circ}$ (decomp.), $\mathrm{C}_{18} \mathrm{H}_{13} \mathrm{ON}_{3} \cdot \mathrm{HCl} \cdot 2 \mathrm{H}_{2} \mathrm{O}$, Mass Spectrum m/e: 


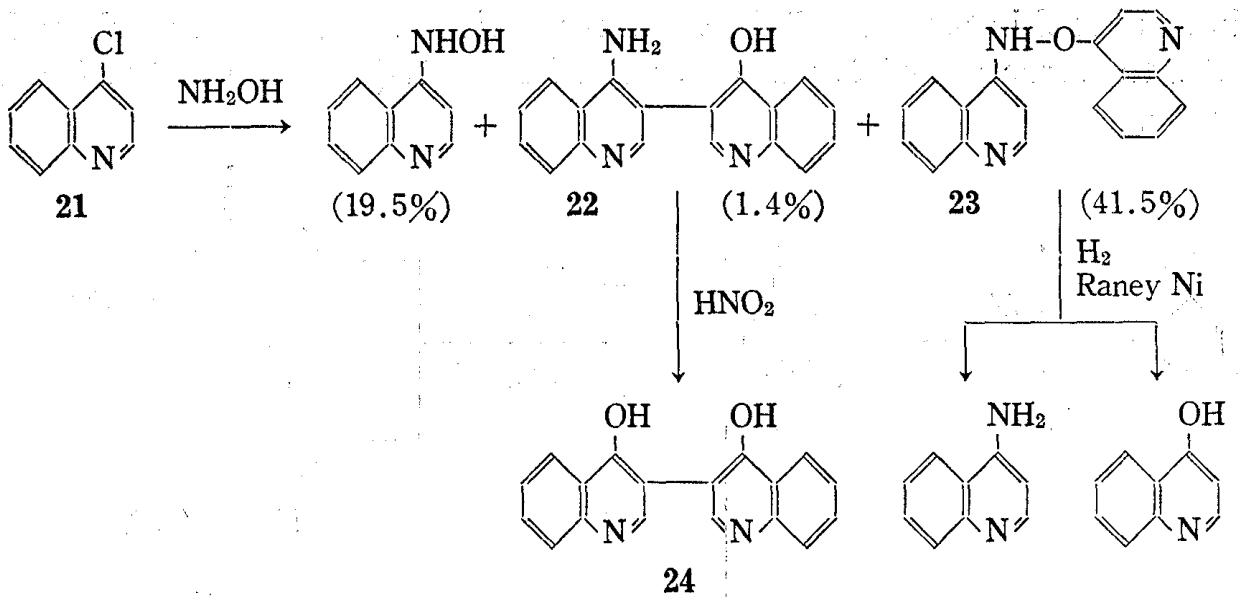

Chart 3

$287\left(\mathrm{M}^{+}\right)$; in addition to $4 \mathrm{HAQ}$ (Chart 3). Treatment of 22 with sodium nitrite gave (24), which was identical with an authentic sample ${ }^{13}$ ) $4,4^{\prime}$-dihydroxy-3,3'-biquinoline, thus the structure of 22 was confirmed to be $3,3^{\prime}$-(4-amino-4'-hydroxy)biquinoline. Catalytic hydrogenation of $\mathbf{2 3}$ over Raney $\mathrm{Ni}$ gave 4-hydroxyquinoline and 4-aminoquinoline in high yield. It was found that 23 was identical with $\mathrm{N}, \mathrm{O}$-di(4-quinolyl)hydroxylamine derived from the reaction of 4-nitroquinoline with hydroxylamine by Hasegawa and Okamoto. ${ }^{14}$

23 would be formed from the reaction of 4-chloroquinoline and once produced 4-hydroxyaminoquinoline, since reaction of $4 \mathrm{HAQ}$ and 4-chloroquinoline gave 23 in relatively high yield. $4 \mathrm{HAQO}$ was also converted into the same compound 23 by the reaction with 4-chloroquinoline, followed by deoxygenation of $\mathrm{N}$-oxide. 23 rearranged to 22 in $\mathrm{CH}_{3} \mathrm{OH}$ by thermolysis at $100^{\circ}$.<smiles>Clc1ccnc2ccccc12</smiles>

21<smiles>O=[N+]([O-])c1ccnc2ccccc12</smiles>

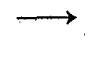<smiles>c1ccc2c(NOc3cccc4ncccc34)ccnc2c1</smiles>

23<smiles>Nc1c(-c2nnc3ccccc3c2O)cnc2ccccc12</smiles>

22

Chart 4

In 1963, Dewar ${ }^{12 b)}$ predicted that N,O-diarylhydroxylamine should be rearranged in the same manner as hydrazobenzenes to give corresponding biphenyl derivatives, but any report had not been published to prove this proposal before our work. Among the efforts related with the proposal, Cox, et al. ${ }^{15)}$ and Sheradsky, et al. ${ }^{16)}$ reported independently that N,Odiarylhydroxylamine would be present as an intermediate in the syntheses of biphenyl derivatives. These reports prompted us to study more, namely the reaction of $4 \mathrm{HAQ}$ with 2,4-dinitrochlorobenzene having active nucleophilic center was examined, as follows.

Reaction of $4 \mathrm{HAQ}$ with 2,4-dinitrochlorobenzene in $\mathrm{CH}_{3} \mathrm{OH}$ under refluxing for 20 minutes afforded (25), mp 185-190 (decomp.), $\mathrm{C}_{15} \mathrm{H}_{10} \mathrm{O}_{5} \mathrm{~N}_{4}$, Mass Spectrum m/e: $326\left(\mathrm{M}^{+}\right)$, NMR Spectrum (in DMSO) $\delta: 8.80(1 \mathrm{H}$, doublet, $J=3 \mathrm{cps}), 8.55(1 \mathrm{H}$, double doublet, $J=9 \mathrm{cps}$, $J=3 \mathrm{cps}$ ), 8.15 (2H, two doublet, $J=9 \mathrm{cps}$ ), $7.80-7.05$ ( $4 \mathrm{H}$, multiplet), 6.43 (1H, doublet, $J=9 \mathrm{cps})$, in $33 \%$ yield. Catalytic hydrogenation of 25 over Raney Ni gave 4-aminoquinoline

13) T. Kosuge, H. Zenda, H. Sawanishi, and Y. Suzuki, Chem. Pharm. Bull. (Tokyo), 17, 2178 (1969).

14) M. Hasegawa and T. Okamoto, Yakugaku Zasshi, 93, 1019 (1973). N,O-diarylhydroxylamines were also reported in following papers. A.S. Bailey, M. Manny, G.W.F. Orpwood, and J.E. White, Tetrahedron, 22, 995 (1966); S. Hashimoto, K. Kano, and I. Takada, Nippon Kagaku Zasshi, 1972, 1960.

15) J.R. Cox and M.F. Dunn, Tetrahedron Letters, 1963, 985.

16) J. Sheradsky and G. Solemnick, Tetrahedron Letters, 1971, 645; idem, Isurael Journal of Chemistry, 10, 857 (1972). 
and 2,4-dinitrophenol in $82 \%$ and $73 \%$ yield, respectively. From the result and analyses of spectral data, the structure of 25 was determined to be $\mathrm{N}$-(4-quinolyl)-O-(2,4-dinitrophenyl)hydroxylamine.<smiles>O=[N+]([O-])C1C=C(Cl)C(=C[In]2C=Nc3ccccc3C2NO)C=C1Cl</smiles><smiles>Nc1cccc2ccccc12</smiles>

$\mathrm{C}_{15} \mathrm{H}_{9} \mathrm{O}_{6} \mathrm{~N}_{3}$<smiles>Cc1ccc2ncc(-c3cc([N+](=O)[O-])cc([N+](=O)[O-])c3O)c(O)c2c1</smiles>

Chart 5

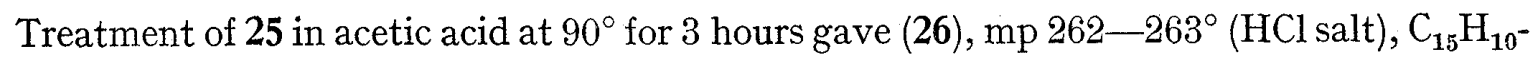
$\mathrm{O}_{5} \mathrm{~N}_{4} \cdot \mathrm{HCl}$, Mass Spectrum m/e: $326\left(\mathrm{M}^{+}\right)$, NMR Spectrum (in $\mathrm{CD}_{3} \mathrm{OD}$ ) $\delta: 8.95(1 \mathrm{H}$, doublet, $J=3 \mathrm{cps}), 8.55(1 \mathrm{H}$, doublet, $J=3 \mathrm{cps}), 8.30$ ( $1 \mathrm{H}$, singlet), $7.95-7.40(4 \mathrm{H}$, multiplet), in $49 \%$ yield. Reaction of 26 with sodium nitrite gave (27), $\mathrm{mp} 283-284^{\circ}, \mathrm{C}_{15} \mathrm{H}_{9} \mathrm{O}_{6} \mathrm{~N}_{3}$, Mass Spectrum $m / e: 327\left(\mathrm{M}^{+}\right)$. From the finding and analyses of spectral data of 26 and 27, the structure of 26 was determined to be 3 -(2'-hydroxy- $3^{\prime}, 5^{\prime}$-dinitrophenyl)-4-aminoquinoline.

From the above results and the reaction of 23 , it would be emphasized that our information reported in this paper is the first chemical proof to Dewar's prediction. Further study on the rearrangement of $\mathbf{2 3}$ and $\mathbf{2 5}$ in various reaction conditions are summarized in Table IV.

TABLE IV. Rearrangement of 23 and 25 in Various Medium

\begin{tabular}{|c|c|c|c|c|c|}
\hline & \multirow{2}{*}{$\begin{array}{l}\text { Temp. } \\
\left({ }^{\circ} \mathrm{C}\right)\end{array}$} & \multirow{2}{*}{$\begin{array}{l}\text { Time } \\
\text { (min) }\end{array}$} & \multicolumn{3}{|c|}{ Solvent and yield } \\
\hline . & & & in $\mathrm{MeOH}$ & in $0.25 \mathrm{M} \mathrm{HCl}-\mathrm{MeOH}$ & in $0.25 \mathrm{M} \mathrm{NaOH}-\mathrm{MeOH}$ \\
\hline $23 \rightarrow 22$ & $\begin{array}{l}60 \\
90\end{array}$ & $\begin{array}{r}80 \\
120\end{array}$ & $81 \%$ & $\begin{array}{r}0 \% \\
60 \%\end{array}$ & $73 \%$ \\
\hline $25 \rightarrow 26$ & 70 & 30 & & $40 \%$ & $81 \%$ \\
\hline
\end{tabular}

The yield was determined from the ultraviolet spectrum.

As shown in Table IV, it was some of interest that the rearrangement favorably proceeded in neutral medium and also in basic medium, in contrast with benzidine rearrangement of hydrazobenzene which required protonation of nitrogen. It was also found that free radical pathway might be excluded in the reaction, since any signal has not been observed in ESR spectra during the thermolysis of $\mathbf{2 3}$ and 25 . Unfortunately, reasonable mechanism for the rearrangement has not been elucidated yet, but further studies of this series on reaction mechanism and in relation to their carcinogenic activity are in progress.

\section{Experimental}

All melting points are determined in open capillary tube and are uncorrected.

Thermolysis of $4 \mathrm{HAQO}$ in $1 \mathrm{~N} \mathrm{HCl}$ - A solution of $\left.4 \mathrm{HAQO} \cdot \mathrm{HCl}^{17}\right)(300 \mathrm{mg})$ in $1 \mathrm{~N} \mathrm{HCl}(5 \mathrm{mI})$ was heated at $200^{\circ}$ for $3 \mathrm{hr}$ in a sealed tube. After removal of the solvent, soluble fraction in $\mathrm{CHCl}_{3}$ with $\mathrm{MeOH}_{(5 \%)}$

17) E. Ochiai and H. Mitarashi, Ann. Rept. ITSUU Lab., 13, 19 (1963). 
was subjected to column chromatography ${ }^{18}$ ) on silica gel eluted with the same solvent to give yellow powders. After neutralization with $1 \mathrm{~N} \mathrm{NaOH}$, recrystallization from $\mathrm{MeOH}$-AcOEt gave 3-chloro-4-aminoquinoline 1 -oxide (1), $\mathrm{mp} 220^{\circ}$ (decomp.). Mass Spectrum m/e: $194\left(\mathrm{M}^{+}\right)$. Anal. Calcd. for $\mathrm{C}_{9} \mathrm{H}_{7} \mathrm{ON}_{2} \mathrm{Cl}: \mathrm{C}, 55.52$; $\mathrm{H}, 3.60 ; \mathrm{N}, 14.40$. Found: $\mathrm{C}, 54.52 ; \mathrm{H}, 3.66 ; \mathrm{N}, 13.98$. UV $\lambda_{\max }^{\mathrm{MeOH}} \mathrm{m} \mu(\varepsilon): 223(27600), 260(12300), 372$ $(8750)$, (223 mg, 79\%).

The same procedure was taken in those cases of reaction temperature at $150^{\circ}, 125^{\circ}, 100^{\circ}$, or $60^{\circ}$.

Diazotization and Reduction of (1)—To a solution of $1(400 \mathrm{mg})$ in a mixture of glacial AcOH $(4 \mathrm{ml})$ and conc. $\mathrm{H}_{2} \mathrm{SO}_{4}(3 \mathrm{ml})$, $n$-butylnitrite $(6 \mathrm{ml})$ was added under cooling with ice water and stirred for $30 \mathrm{~min}$. Cold acetone $(50 \mathrm{ml}$ ) and ether (about $300-400 \mathrm{ml}$ ) were added to the reaction mixture to make precipitation. The diazonium salt was collected by filtration and was reduced by boiling in EtOH ( $30 \mathrm{ml})$ for 30 min. After removal of the solvent, the residue was made alkaline with $1 \mathrm{~N} \mathrm{NaOH}$ and extracted with $\mathrm{CHCl}_{3}$. The product was subjected to column chromatography on silica gel eluted with $\mathrm{CHCl}_{3}$ to give $2, \mathrm{mp} 100-101^{\circ}$ (recrystallized from a mixture of petr. ether-benzene). Mass Spectrum m/e: $179\left(\mathrm{M}^{+}\right)$, monochloride (50 mg, $\left.13.5 \%\right)$.

Reduction of $2-2(80 \mathrm{mg})$ in $\mathrm{MeOH}$ was hydrogenated over Raney Ni prepared from nickel aluminum alloy $(300 \mathrm{mg})$. After removal of the catalyst by filtration and of the solvent by evaporation, the residue was subjected to column chromatography on silica gel eluted with $\mathrm{CHCl}_{3}$ to give 3-chloroquinoline (3), $\mathrm{mp}$ $185-186^{\circ}$ (picrate) $(45 \mathrm{mg}, 61.8 \%$ ). The product was identified with the authentic sample synthesized by the method of J.C. Cochran.7)

Thermolysis of 4-Hydroxyaminoquinaldine 1-0xide (4) in $1_{\mathrm{N}} \mathrm{HCl}$-A suspension of $\left.4 \cdot \mathrm{HCl}^{19}\right)(445 \mathrm{mg})$ in $1 \mathrm{~N} \mathrm{HCl}(8 \mathrm{ml})$ was heated at $180^{\circ}$ for $6 \mathrm{hr}$ in a sealed tube. After removal of the solvent, the soluble fraction of the residue in $\mathrm{MeOH}$ was subjected to column chromatography on silica gel eluted with $\mathrm{MeOH}_{-} \mathrm{CHCl}_{3}$ to give yellow powders. The salt isolated was made free by treatment with $1 \mathrm{~N} \mathrm{NaOH}$. Recrystallization from MeOH-AcOEt gave (5), mp 222 . Mass Spectrum m/e: $208\left(\mathrm{M}^{+}\right)$. Anal. Calcd. for $\mathrm{C}_{10} \mathrm{H}_{9} \mathrm{ON}_{2} \mathrm{Cl}^{\circ} \mathrm{CH}_{3^{-}}$ $\mathrm{OH}: \mathrm{C}, 54.97 ; \mathrm{H}, 5.41 ; \mathrm{N}, 11.66$. Found: $\mathrm{C}, 54.31 ; \mathrm{H}, 5.20 ; \mathrm{N}, 11.68$. UV $\lambda_{\max }^{\mathrm{MeOH}} \mathrm{m} \mu(\varepsilon): 221(33500), 258$ (20900), $263(20400), 364$ (9880), (298.6 mg, 63.2\%).

$5(200 \mathrm{mg})$ in $\mathrm{MeOH}$ was hydrogenated over Raney $\mathrm{Ni}$, prepared from nickel aluminum alloy (300 $\mathrm{mg})$, to give a deoxygenated compound, 3-chloro-4-aminoquinaldine, $\mathrm{mp} 209-210^{\circ}$. Mass Spectrum $m / e: 192$ $\left(\mathrm{M}^{+}\right)$. UV $\lambda_{\max }^{\mathrm{MeOH}} \mathrm{m} \mu(\varepsilon): 218(33100), 243(31000), 313(8050)$. NMR (in $\left.\mathrm{CD}_{3} \mathrm{OD}\right) \delta: 7.23-8.23$ (4H, multiplet), 2.58 (3H, singlet). (140 mg, $75 \%$ ).

Thermolysis of 4 in $6 \mathrm{~N} \mathrm{HCl}$-A suspension of $4 . \mathrm{HCl}(480 \mathrm{mg})$ in $6 \mathrm{~N} \mathrm{HCl}(10 \mathrm{ml})$ was heated at $180^{\circ}$ for $6 \mathrm{hr}$ in a sealed tube. Procedure for isolation of the product was carried out as same as the above reaction to give 5 (405.4 $\mathrm{mg}, 79.5 \%$ ).

Thermolysis of $4 \mathrm{HAQ}$ in $1 \mathrm{~N} \mathrm{HCl}$ - - A solution of $\left.4 \mathrm{HAQ} \cdot \mathrm{HCl}^{20}\right)(201.7 \mathrm{mg})$ in $1 \mathrm{~N} \mathrm{HCl}(5 \mathrm{ml})$ was heated at $220^{\circ}$ for $7 \mathrm{hr}$ in a sealed tube. After cooling, the precipitate was collected by filtration and extracted with $\mathrm{MeOH}$. From $\mathrm{MeOH}$ solution was given $4 \mathrm{HAQ} \cdot \mathrm{HCl}(82.4 \mathrm{mg})$.

$\mathrm{MeOH}$ insoluble part was subjected to column chromatography on silica gel, eluted with $\mathrm{MeOH}-\mathrm{CHCl}_{3}$ to give the following three compounds.

3-chloro-4-hydroxyquinoline $(6)^{21)}(12.6 \mathrm{mg}, 9.4 \%)$.

4-hydroxyquinoline $(7)^{22)}(45.5 \mathrm{mg}, 42.1 \%)$.

4-aminoquinoline $(8)^{23)}(43.7 \mathrm{mg}$ as $\mathrm{HCl}$ salt, $39.9 \%)$

These yields are based on the reacted starting material.

Thermolysis of 4-Hydroxyaminopyridine 1-0xide (9) in $3 \mathrm{~N} \mathrm{HCl}$-A solution of $9^{24)}(644.2 \mathrm{mg})$ in $3 \mathrm{~N}$ $\mathrm{HCl}(12 \mathrm{ml})$ was heated at $210^{\circ}$ for $3 \mathrm{hr}$ in a sealed tube. After removal of the solvent, soluble fraction of the residue in $\mathrm{MeOH}$ was subjected to column chromatography on silica gel, and a fraction eluted with $2 \%$ $\mathrm{MeOH}$ in $\mathrm{CHCl}_{3}$ was subjected to column chromatography on Sephadex $\mathrm{LH}-20$ eluted with $\mathrm{MeOH}$ to give

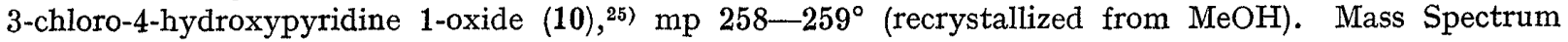
m/e: $145\left(\mathrm{M}^{+}\right)$. Anal. Calcd. for $\mathrm{C}_{5} \mathrm{H}_{4} \mathrm{O}_{2} \mathrm{NCl}: \mathrm{C}, 42.76 ; \mathrm{H}, 2.79 ; \mathrm{N}, 9.66$. Found: $\mathrm{C}, 41.56 ; \mathrm{H}, 2.96 ; \mathrm{N}, 9.51$ $(138.0 \mathrm{mg}, 20.9 \%)$.

A fraction eluted with $4 \% \mathrm{MeOH}$ in $\mathrm{CHCl}_{3}$ on silica gel column chromatography was purified by chromatography on Sephadex LH-20 eluted with $\mathrm{MeOH}$ to give 4-hydroxypyridine $(11)^{26)}(78.2 \mathrm{mg}, 16.1 \%$ ).

18) Only this procedure succeeded in the isolation of desirable product without any trouble caused by unreacted $4 \mathrm{HAQO}$.

19) E. Ochiai and H. Mitarashi, Ann. Rept. ITSUU Lab., 14, 17 (1965).

20) M. Hamana and K. Funakoshi, Yakugaku Zasshi, 84, 42 (1964).

21) A.R. Surrey and R.A. Cutler, J. Am. Chem. Soc., 68, 2570 (1946).

22) E. Hayashi, H. Yamanaka, and K. Shimizu, Chem. Pharm. Bull. (Tokyo), 7, 146 (1959).

23) E. Ochiai and T. Naito, Yakugaku Zasshi, 64, 206 (1944).

24) E. Ochiai and H. Mitarashi, Chem. Pharm. Bull. (Tokyo), 11, 1084 (1963).

25) H.J. den Hertog and W.P. Combe, Rec. Trav. Chim., 71, 745 (1952) [C.A., 47, 5938c (1953)].

26) E. Hayashi, H. Yamanaka, and K. Shimizu, Chem. Pharm. Bull. (Tokyo), 7, 141 (1959). 
Thermolysis of 4-Hydroxyamino-2-picoline 1-Oxide (12) in $3 \mathrm{~N} \mathbf{H C l}$ - - A solution of 1219) (301.8 $\mathrm{mg})$ in $3 \mathrm{~N} \mathrm{HCl}(6 \mathrm{ml})$ was heated at $210^{\circ}$ for $3 \mathrm{hr}$ in a sealed tube. After removal of the solvent, the residue was extracted with $\mathrm{EtOH}$, and recrystallization from $\mathrm{MeOH}$-AcOEt gave 4-amino-3-chloro-2-picoline 1-oxide (13) in $5.2 \%$ yield. $m p 230^{\circ}$ (decomp.). Mass Spectrum m/e: $158\left(\mathrm{M}^{+}\right)$. Anal. Calcd. for $\mathrm{C}_{6} \mathrm{H}_{7} \mathrm{ON}_{2} \mathrm{Cl} \cdot \mathrm{HCl}$ : $\mathrm{C}, 37.11 ; \mathrm{H}, 4.16 ; \mathrm{N}, 14.33$. Found: $\mathrm{C}, 36.91 ; \mathrm{H}, 4.14 ; \mathrm{N}, 14.49$. UV $\lambda_{\max }^{\mathrm{MeOH}} \mathrm{m} \mu(\varepsilon): 280(14800)$. NMR (in $6 d$-DMSO) $\delta: 8.23(1 \mathrm{H}$, doublet, $J=8 \mathrm{cps}), 7.95(2 \mathrm{H}$, broad singlet), 6.93 (1H, doublet, $J=8 \mathrm{cps}), 2.63$ (3H, singlet).

Recrystallization of the insoluble part in EtOH gave colorless needles (14), mp $239^{\circ}$ (decomp.). Mass Spectrum m/e: $244\left(\mathrm{M}^{+}\right)$. Anal. Calcd. for $\mathrm{C}_{12} \mathrm{H}_{14} \mathrm{O}_{2} \mathrm{~N}_{4} \cdot 2 \mathrm{H}_{2} \mathrm{O} \cdot \mathrm{HCl}: \mathrm{C}, 45.57 ; \mathrm{H}, 6.01 ; \mathrm{N}, 17.72$. Found: $\mathrm{C}, 45.82 ; \mathrm{H}, 6.12 ; \mathrm{N}, 17.27$. UV $\lambda_{\max }^{\mathrm{Meor}} \mathrm{m} \mu .(\varepsilon): 284(28000)$. (105.5 $\left.\mathrm{mg}, 30.9 \%\right)$. The structure of the compound has not been clarified yet.

Thermolysis of 4-Hydroxyamino-3-picoline 1-Oxide (15) in $3 \mathrm{~N} \mathbf{H C l}$-A solution of $15^{19)}(2.00 \mathrm{~g})$ in $3 \mathrm{~N}$ $\mathrm{HCl}(20 \mathrm{ml})$ was heated at $220^{\circ}$ for $3 \mathrm{hr}$ in a sealed tube. After removal of the solvent, the residue was washed with $\mathrm{EtOH}(10 \mathrm{ml})$ and with $5 \% \mathrm{EtOH}$ in $\mathrm{CHCl}_{3}(10 \mathrm{ml})$, and the insoluble part was subjected to column chromatography on silica gel eluted with $\mathrm{MeOH}-\mathrm{CHCl}_{3}$ to give 4-amino-5-chloro-3-picoline 1-oxide (16), mp $218^{\circ}$ (decomp.). Mass Spectrum m/e: $158\left(\mathrm{M}^{+}\right)$. Anal. Calcd. for $\mathrm{C}_{6} \mathrm{H}_{7} \mathrm{ON}_{2} \mathrm{Cl} \cdot \mathrm{HCl}: \mathrm{C}, 37.11 ; \mathrm{H}, 4.16 ; \mathrm{N}$, 14.43. Found: $\mathrm{C}, 38.65 ; \mathrm{H}, 4.83 ; \mathrm{N}, 14.48$. UV $\lambda_{\max }^{\mathrm{MeOH}} \mathrm{m} \mu(\varepsilon): 216(21600), 286(18800)$. NMR (in 6d-DMSO) $\delta: 8.35$ (1H, singlet), $8.00(1 \mathrm{H}$, singlet), 7.10 (2H, broad singlet), 2.10 (3H, singlet) $(1.21 \mathrm{~g}, 53.6 \%)$.

Thermolysis of $4 \mathrm{HAQO}$ in $2 \mathrm{~N} \mathrm{HBr}$ - A solution of $4 \mathrm{HAQO} \cdot \mathrm{HBr}(300 \mathrm{mg})$ in $2 \mathrm{~N} \mathrm{HBr}(5 \mathrm{ml})$ was heated at $240^{\circ}$ for $3 \mathrm{hr}$ in a sealed tube. After removal of the solvent, the residue was subjected to column chromatography on cellulose eluted with $\mathrm{MeOH}$ to give a yellow powder. The $\mathrm{HBr}$ salt was made free by treatment with $1 \mathrm{~N} \mathrm{NaOH}$, and recrystallization from $\mathrm{MeOH}$-AcOEt gave 4-aminoquinoline 1-oxide (17), ${ }^{23)} \mathrm{mp} 274^{\circ}$ (decomp.). (141.0 mg, 50.1\%).

Thermolysis of 4 in $2 \mathrm{~N} \mathrm{HBr}$ - A solution of $4 . \mathrm{HBr}(300 \mathrm{mg})$ in $2 \mathrm{~N} \mathrm{HBr}(8 \mathrm{ml})$ was heated at $180^{\circ}$ for $6 \mathrm{hr}$ in a sealed tube. After removal of the solvent, soluble fraction of the residue in $\mathrm{MeOH}$ was subjected to column chromatography on silica gel eluted with $\mathrm{MeOH}-\mathrm{CHCl}_{3}$ to give yellow powders $(\mathbf{1 8}), \mathrm{mp} 240^{\circ}$ (decomp.) (recrystallized from the mixture of $\mathrm{MeOH}-\mathrm{AcOEt}$ ). Mass Spectrum m/e: $174\left(\mathrm{M}^{+}\right)$. Anal. Calcd. for $\mathrm{C}_{10} \mathrm{H}_{10} \mathrm{ON}_{2} \cdot \mathrm{HBr} \cdot \mathrm{H}_{2} \mathrm{O}: \mathrm{C}, 43.95 ; \mathrm{H}, 4.81 ; \mathrm{N}, 10.25$. Found : $\mathrm{C}, 43.52 ; \mathrm{H}, 4.79 ; \mathrm{N}, 10.20 .(139.0 \mathrm{mg}, 49.2 \%)$.

$18(100 \mathrm{mg})$ in $\mathrm{MeOH}$ was hydrogenated over Raney $\mathrm{Ni}$, prepared from nickel aluminum alloy $(200 \mathrm{mg})$. The reaction mixture was made alkaline by treatment with $1 \mathrm{~N} \mathrm{NaOH}$, evaporated to dryness, and the residue was subjected to column chromatography on silica gel using $\mathrm{MeOH}-\mathrm{CHCl}_{3}$ to give 4-aminoquinaldine, ${ }^{27}$ ) $\mathrm{mp} 163^{\circ}$ (recrystalized from benzene). Mass Spectrum $m / e: 158\left(\mathrm{M}^{-}{ }^{-}\right)(48.3 \mathrm{mg}, 78.0 \%)$.

Thermolysis of $4 \mathbf{H A Q}$ in $2 \mathrm{~N} \mathbf{~ H B r}$-A solution of $4 \mathrm{HAQ} \cdot \mathrm{HBr}(205.1 \mathrm{mg})$ in $2 \mathrm{~N} \mathrm{HBr}(5 \mathrm{ml})$ was heated at $220^{\circ}$ for $7 \mathrm{hr}$ in a sealed tube. The precipitate was collected by filtration and was extracted with $\mathrm{MeOH}$ to give $4 \mathrm{HAQ} \cdot \mathrm{HBr} .(128.3 \mathrm{mg})$. After the removal of the solvent of the filtrate in vacuo, the residue was subjected to column chromatography on silica gel using $5 \% \mathrm{MeOH}$ in $\mathrm{CHCl}_{3}$ to give yellow powders. The $\mathrm{HBr}$ salt was made free by treatment with $1 \mathrm{~N} \mathrm{NaOH}$, and recrystallization from benzene gave 8 . mp $153-154^{\circ}$ $(64 \mathrm{mg}, 89.3 \%)$. This yield is based on the reacted starting material.

Thermolysis of $4 \mathrm{HAQO}$ in conc. $\mathrm{HBr}-\mathrm{A}$ solution of $4 \mathrm{HAQO}(300 \mathrm{mg})$ in conc. $\mathrm{HBr}(6 \mathrm{ml})$ was heated at $180^{\circ}$ for $3 \mathrm{hr}$ in a sealed tube. After the reaction mixture was neutralized, precipitate was collected by filtration, and was subjected to column chromatography on silica gel eluted with $\mathrm{MeOH}-\mathrm{CHCl}_{3}$ to give 3bromo-4-aminoquinoline 1-oxide (19). mp 202-203 (recrystallized from EtOH). (297.1 mg, 71.4\%). The structure of the product was identified with the authentic sample. ${ }^{9)}$

Reaction of 4-Chloroquinoline $(21)^{22)}$ and Hydroxylamine-To a solution of hydroxylamine $\cdot \mathrm{HCl}$ $(6.31 \mathrm{~g})$ in $\mathrm{MeOH}(100 \mathrm{ml}), \mathrm{MeOH}$ saturated with $\mathrm{K}_{2} \mathrm{CO}_{3}$ was added to neutralize the solution, and the precipitated $\mathrm{KCl}$ was removed by filtration. To the filtrate, a solution of $21(3 \mathrm{~g})$ in $\mathrm{MeOH}(20 \mathrm{ml})$ was added and the mixture was refluxed for $5.5 \mathrm{hr}$. The red needles precipitated was collected by filtration, washed with small amount of $\mathrm{MeOH}$ and recrystallized from $\mathrm{MeOH}$ to give $\mathrm{N}, \mathrm{O}$-di(quinolyl)hydroxylamine $(\mathbf{2 3}) \cdot \mathrm{HCl}$. $(1.37 \mathrm{~g}, 41.5 \%)$. mp $168^{\circ}$ (decomp.). Anal. Calcd. for $\mathrm{C}_{18} \mathrm{H}_{13} \mathrm{ON}_{3} \cdot 2 \mathrm{H}_{2} \mathrm{O} \cdot \mathrm{HCl}$ : C, 60.18; H, 5.02; N, 11.71 . Found: C, 61.21; H, 5.08; N, 11.99. Mass Spectrum $m / e: 287\left(\mathrm{M}^{+}\right) . \quad \mathrm{UV} \lambda_{\max }^{\mathrm{MeOH}} \operatorname{m} \mu(\varepsilon): 225(38900), 380$ $(13600)$.

Concentration of the mother liquid yielded $4 \mathrm{HAQ} \cdot \mathrm{HCl}(701 \mathrm{mg}, 19.5 \%)$, identified with an authentic sample. ${ }^{20)}$

Further concentration of the mother liquid removed $4 \mathrm{HAQ} \cdot \mathrm{HCl}$ gave $3,3^{\prime}$-(4-amino-4'-hydroxy) biquinoline $\cdot \mathrm{HCl}(22), \mathrm{mp}>300^{\circ}$. (recrystallized from $\mathrm{H}_{2} \mathrm{O}-\mathrm{MeOH}$ ). Anal. Calcd. for $\mathrm{C}_{18} \mathrm{H}_{13} \mathrm{ON}_{3} \cdot \mathrm{H}_{2} \mathrm{O} \cdot 3 \mathrm{HCl}$ : $\mathrm{C}, 52.11 ; \mathrm{H}, 4.34 ; \mathrm{N}, 10.13$. Found: $\mathrm{C}, 51.96 ; \mathrm{H}, 4.46 ; \mathrm{N}, 9.60$. Mass Spectrum $m / e: 287\left(\mathrm{M}^{+}\right)$. UV $\lambda_{\max }^{\mathrm{MeOH}}$ $\mathrm{m} \mu(\varepsilon): 216(55100), 332(28300)$. (54 mg, 1.4\%).

Reaction of 22 with $\mathrm{NaNO}_{2}$ — To a solution of $22(208 \mathrm{mg})$ in a mixture of glacial AcOH $(4 \mathrm{ml})$ and conc. $\mathrm{H}_{2} \mathrm{SO}_{4}(2 \mathrm{ml}), \mathrm{NaNO}_{2}(1 \mathrm{~g})$ in cold water $(2 \mathrm{ml})$ was added dropwise under cooling with ice water. After

27) G. Buchmann, Ger. (East) 24330 (Cl. 12p), Nov. 28, (1962), Appl. Mar. 11, (1959); 2pp [C.A., 59, $10008 a$ (1963)]. 
standing for $24 \mathrm{hr}$ at room temperature, the mixture was neutralized with conc. $\mathrm{NaOH}$ solution. Produced precipitates were collected by filtration, washed with water, and recrystallized from $\mathrm{MeOH}-\mathrm{AcOEt}$ after treatment with $\mathrm{HCl}$ to give $3,3^{\prime}$-(4,4'-dihydroxy) biquinoline $\cdot \mathrm{HCl}$ (24). $\mathrm{mp}>300^{\circ}$. $(60 \mathrm{mg})$.

Reduction of 23-A suspension of $23(90 \mathrm{mg})$ in $\mathrm{MeOH}(20 \mathrm{ml})$ was hydrogenated over Raney $\mathrm{Ni}$, prepared from nickel aluminum alloy $(600 \mathrm{mg})$. After removal of the catalyst by filtration and of the solvent by evaporation in vacuo, the residue was subjected to column chromatography on silica gel to give two compounds, 7 (33 mg, 91\%) (recrystallized from MeOH-AcOEt) and 8 (35 mg, 96\%) (recrystallized from MeOHbenzene).

Reaction of $4 \mathrm{HAQ}$ and 21 - To a solution of $4 \mathrm{HAQ} \cdot \mathrm{HCl}(1.25 \mathrm{~g})$ in $\mathrm{MeOH}(30 \mathrm{ml}), \mathrm{MeOH}$ saturated with $\mathrm{K}_{2} \mathrm{CO}_{3}$ was added until the solution was neutralized, and precipitated $\mathrm{KCl}$ was removed by filtration. To the filtrate, a solution of $21(1 \mathrm{~g})$ in $\mathrm{MeOH}(20 \mathrm{ml})$ was added, and the mixture was refluxed for $5.5 \mathrm{hr}$. The red needle precipitates were collected by filtration, washed with small amount of $\mathrm{MeOH}$ and recrystallized from $\mathrm{MeOH}$ to give $23 \cdot \mathrm{HCl}(843 \mathrm{mg}, 38 \%$ based on $4 \mathrm{HAQ} \cdot \mathrm{HCl})$.

Reaction of $4 \mathrm{HAQ}$ and 21 - A suspension of $4 \mathrm{HAQO}(352 \mathrm{mg})$ and $21(328 \mathrm{mg})$ in $\mathrm{MeOH}(20 \mathrm{ml})$ was refluxed for $1 \mathrm{hr}$ and evaporated to dryness. The residue was washed with $\mathrm{CHCl}_{3}$, and recrystallized from $\mathrm{HCl}-\mathrm{MeOH}$ to give $23 \cdot \mathrm{HCl}$. (237 $\mathrm{mg}, 33 \%$ based on $4 \mathrm{HAQO}$ ).

Rearrangement of 23 - A suspension of $23(300 \mathrm{mg})$ in $\mathrm{MeOH}(10 \mathrm{ml})$ was heated at $100^{\circ}$ for $1.5 \mathrm{hr}$ in a sealed tube. The resulted precipitates were collected by filtration and recrystallized from $\mathrm{HCl}-\mathrm{MeOH}$ to give $22, \mathrm{mp}>300^{\circ}(152 \mathrm{mg}, 36 \%)$.

Preparation of N-(4-Quinolyl)-0-(2,4-dinitrophenyl)hydroxylamine (25)_-To a solution of $\mathrm{MeOH}$ $(120 \mathrm{ml})$ with $\mathrm{K}_{2} \mathrm{CO}_{3}(800 \mathrm{mg})$, $4 \mathrm{HAQ} \cdot \mathrm{HCl}(2000 \mathrm{mg})$ was added and the produced $\mathrm{KCl}$ was removed by filtration. To the filtrate, 2,4-dinitrochlorobenzene $(2335 \mathrm{mg})$ was added and the mixture was refluxed for $20 \mathrm{~min}$. Precipitates were collected by filtration, washed with $\mathrm{MeOH}$ to give red product, 25, $\mathrm{mp} 185-190^{\circ}$ (decomp.). Anal. Calcd. for $\mathrm{C}_{15} \mathrm{H}_{10} \mathrm{O}_{5} \mathrm{~N}_{4}: \mathrm{C}, 55.21 ; \mathrm{H}, 3.07 ; \mathrm{N}, 17.18$. Found: $\mathrm{C}, 55.18 ; \mathrm{H}, 3.36 ; \mathrm{N}, 17.28$. Mass Spectrum $m / e: 326\left(\mathrm{M}^{+}\right)$. UV $\lambda_{\max }^{\text {Meor }} m \mu(\varepsilon): 226(50900), 385$ (18400). NMR (in DMSO) $\delta: 8.80(1 \mathrm{H}$, doublet, $J=3 \mathrm{cps}$ ), 8.55 ( $1 \mathrm{H}$, double doublet, $J=9 \mathrm{cps}, J=3 \mathrm{cps}$ ), 8.15 ( $2 \mathrm{H}$, two doublet, $J=9 \mathrm{cps}$ ), 7.80 $7.05(4 \mathrm{H}$, multiplet), $6.43(1 \mathrm{H}$, doublet, $J=9 \mathrm{cps})(1100 \mathrm{mg}, 33 \%)$.

Rearrangement of 25 - A suspension of $25(200 \mathrm{mg})$ in glacial AcOH $(150 \mathrm{ml})$ was heated at $90^{\circ}$ for $3 \mathrm{hr}$ in a sealed tube. After removal of the solvent by evaporation in vacuo, the residue was recrystallized from $\mathrm{MeOH}$-AcOEt with $\mathrm{HCl}$ to give $3-\left(2^{\prime}\right.$-hydroxy-3', $5^{\prime}$-dinitrophenyl $)$-4-aminoquinoline $\cdot \mathrm{HCl}(26)$. $\mathrm{mp}$ 262-263․ Anal. Calcd. for $\mathrm{C}_{15} \mathrm{H}_{10} \mathrm{O}_{5} \mathrm{~N}_{4} \cdot \mathrm{HCl}: \mathrm{C}, 49.66 ; \mathrm{H}, 3.03 ; \mathrm{N}, 15.45$. Found: $\mathrm{C}, 49.19 ; \mathrm{H}, 3.22 ; \mathrm{N}$, 15.18. Mass Spectrum $m / e: 326\left(\mathrm{M}^{+}\right)$. UV $\lambda_{\max }^{\mathrm{Meor}} \mathrm{m} \mu(\varepsilon): 245(33000), 326(18500) . \quad \mathrm{NMR}$ (in $\left.\mathrm{CD}_{3} \mathrm{OD}\right) \delta$ : $8.95(1 \mathrm{H}$, doublet, $J=3 \mathrm{cps}), 8.55(1 \mathrm{H}$, doublet, $J=3 \mathrm{cps}), 8.30$ (1H, singlet), $7.95-7.40$ (4H, multiplet) (109 $\mathrm{mg}, 49 \%$ ).

Reduction of 25-A suspension of $25(200 \mathrm{mg})$ in a mixture of $1 \mathrm{~N} \mathrm{HCl}(10 \mathrm{ml})$ and $\mathrm{MeOH}(200 \mathrm{ml})$ was hydrogenated over Raney Ni, prepared from nickel aluminum alloy (300 mg). After removal of the catalyst by filtration and of the solvent by evaporation in vacuo, the residue was acidified with $1 \mathrm{~N} \mathrm{HCl}$ and extracted with $\mathrm{CHCl}_{3}$ to give 2,4-dinitrophenol (82 $\mathrm{mg}, 73 \%$ ).

The $\mathrm{CHCl}_{3}$ insoluble layer gave $8(72 \mathrm{mg}, 82 \%)$.

Reaction of 26 with $\mathrm{NaNO}_{2} \longrightarrow$ To a solution of $26(80 \mathrm{mg})$ in diluted $\mathrm{H}_{2} \mathrm{SO}_{4}(0.5 \mathrm{ml} \rightarrow 10 \mathrm{ml}), \mathrm{NaNO}_{2}$ $(0.5 \mathrm{~g})$ in cold water $(2 \mathrm{ml})$ was added dropwise under cooling with ice water and the reaction mixture was kept under cooling for $5 \mathrm{~min}$, followed by at $60^{\circ}$ for $10 \mathrm{~min}$, and neutralized with conc. $\mathrm{NaOH}$ solution. The resulted precipitates were collected by filtration and recrystallized from $\mathrm{MeOH}-\mathrm{AcOE}$ t to give $27, \mathrm{mp}$ $283-284^{\circ}$. Anal. Calcd. for $\mathrm{C}_{15} \mathrm{H}_{9} \mathrm{O}_{6} \mathrm{~N}_{3}: \mathrm{C}, 55.05 ; \mathrm{H}, 2.75 ; \mathrm{N}, 12.88$. Found: $\mathrm{C}, 55.25 ; \mathrm{H}, 2.27 ; \mathrm{N}, 12.94$. Mass Spectrum $m / e: 327\left(\mathrm{M}^{+}\right)$. UV $\lambda_{\max }^{\mathrm{MeOH}} \operatorname{m} \mu(\varepsilon): 248(27500)$.

Measurement of Electron Spin Resonance Spectra-_-When a solution of $\mathbf{2 3}$ or 25 dissolved in DMF was warmed at $60-100^{\circ}$, any spectra have not been observed.

Apparatus: Japan Electron Optics Laboratory JES-3BX spectrometer

Modulation: $100 \mathrm{Kc} / \mathrm{s}$

Acknowledgement The authors are deeply indebted to Professor T. Kosuge of their laboratory for his kind support and encouragement. The authors want to express their sincere thanks to Dr. H. Zenda for his valuable discussion about the halogenation. 